\title{
Best Practice Pengembangan dan Penerapan Teknologi Tepat Guna
}

\author{
Megawati Megawati ${ }^{1}$, Adianto Adianto ${ }^{2}$ \\ ${ }^{1,2}$ Program Studi Ilmu Administrasi Publik, Fakultas Ilmu Sosial dan Ilmu Politik, \\ Universitas Riau \\ Email : Megaa261099@gmail.com ${ }^{1}$, adianto@1ecturer.unri.ac.id $^{2}$
}

Dikirim : 13 April 2021 | Direvisi : 23 April 2021 | Diterima : 14 Juni 2021

\begin{abstract}
ABSTRAK
Desa Kundur mengembangkan beberapa TTG untuk membantu masyarakat dalam melakukan pekerjaan sebagai petani sehari-hari. Lahan gambut yang dimiliki Desa Kundur sangat subur, tetapi air yang dihasilkan tanah gambut tidak baik untuk dikonsumsi,. Sedangkan saat musim kemarau persediaan air hujan habis, masyarakat menggunakan air sumur gambut untuk dikonsumsi. Hal tersebut mendorong pemerintah desa berinisiatif untuk untuk mengajukan proposal ke Kementrian Desa PDDT dengan permohonan membuat alat tepat guna untuk mengolah air gambut menjadi air minum, ide tersebut disetujui dan bantuan disalurkan melalui tim pelaksana kegiatan PIID-PEL . Penelitian ini bertujuan untuk mengetahui bagaimana proses pengembangan dan penerapan teknologi tepat guna pengelolaan air minum di Desa Kundur serta faktor penghambat yang mempengaruhi. Menggunakan metode penelitian kualitatif dengan pendekatan studi kasus yang bersifat deskriptif. Konsep teori yang digunakan adalah teori (Prasojo, Eko, 2007) ada beberapa kriteria untuk menilai sebuah best practice. Hasil penelitian ditemukan bahwa penerapan TTG pengelolaan air minum Desa Kundur berhasil diterapkan dan memberikan dampak yang baik bagi kehidupan masyarakat serta pemerintah Desa Kundur .Tetapi penerapan tersebut belum maksimal dikarenakan masih ditemukannya faktor penghambat dalam pengembangan dan penerapan TTG pengelolaan air minum di Desa Kundur, yaitu strategi pemasaran, legalitas hukum yang belum lengkap, dan anggaran yang masih minim
\end{abstract}

Kata Kunci: Teknologi Tepat Guna; Air Minum; Pengembangan dan Penerapan

\begin{abstract}
Kundur village developed several TTGs to assist the community in doing daily work as farmers. The peat land owned by Kundur is very fertile, but the water produced by the peat soil is not good for consumption. Meanwhile, during the dry season the supply of rainwater runs out, the community uses peat well water for consumption. This prompted the village government to take the initiative to submit a proposal to the Ministry of Village for PDDT with a request for an appropriate tool to process peat water into drinking water, the idea was approved and assistance channeled through the PIID-PEL activity implementation team. This study aims to determine how the process of developing and applying appropriate technology for drinking water management in Kundur village and the inhibiting factors that affect it. Using qualitative research methods with a descriptive case study approach. The theoretical concept used is
\end{abstract}


theory (Prasojo, Eko, 2007). There are several criteria for assessing a best practice. The results of the study found that the implementation of TTG for drinking water management in Kundur Village was successfully implemented and had a good impact on the lives of the community and the Kundur village government. However, the implementation has not been maximal because inhibiting factors are still found in the development and implementation of TTG for drinking water management in Kundur, namely marketing strategies, incomplete legal legality, and minimal budget.

Keywords: Appropriate Technology; Drinking Water; Development and Application.

\section{PENDAHULUAN}

Desa Kundur adalah salah satu desa yang memanfaatkan teknologi tepat guna untuk membantu pekerjaan masyarakat dengan inovasi-inovasi yang baru dalam membuat alat-alat tepat guna dengan memperhatikan apa yang menjadi masalah dan apa yang dibutuhkan masyarakat Desa Kundur sehingga teknologi yang dibuat tidak sia-sia dan berlanjut. Sesuai dengan visi dan misi Desa Kundur yang ingin memajukan desa melalui potensi desa yakni sektor pertanian dan perkebunan. Masyarakat yang mayoritas sebagai petani selama ini masih melakukan pekerjaan secara manual yang tentunya lebih membutuhkan waktu yang lama dan tenaga, dengan adanya teknologi tepat guna pekerjaan menjadi mudah dilakukan dan akan berdampak bagi ekonomi masyarakat. Undang-undang No 6 tahun 2014 tentang Desa telah memberikan kewenangan kepada desa untuk mengurus dan memajukan desa, membangun kemandirian dengan memecahkan masalah dengan potensi desa dengan tujuan untuk memberikan kesejahtraan kepada warga desa dan kemajuan terhadap desa. Desa bukan lagi organisasi pemerintah yang menunggu perintah, akan tetapi desa sudah memiliki hak dalam mengambil tindakan untuk kemajuan desa dengan ketentuan undang-undang. Upaya memberdayakan potensi desa perlu terus dilakukan mengikuti arus perkembangan ilmu pengetahuan dan teknologi agar kualitas sumber daya manusia dan sumber daya alam yang sangat potensial untuk meningkatkan kesejahtraan masyarakat jika dikelola dengan baik maka desa dapat mencapai tujuan yang dicita-citakan.

Amanah undang-undang tersebut, mendorong pemerintah Desa Kundur untuk berfikir keras mengambil keputusan dalam memecahkan masalah yang dialami desa tesebut.Desa Kundur dianugrahi tanah bergambut yang subur memberikan kehidupan bagi masyarakat melalui bercocok tanam.Potensi desa sektor perkebunan dan pertanian membawa kemakmuran, tidak hanya penduduk lokal desa tetapi juga mempengaruhi penduduk diluar desa.Akan tetapi tanah yang subur membawa kemakmuran tersebut tidak memberikan efek yang baik bagi salah satu kebutuhan yang sangat penting terhadap manusia yaitu air.Struktur tanah yang bergambut menghasilkan air berwarna coklat dan asam yang selama ini masyarakat gunakan dalam memenuhi kebutuhan sanitasi sehari-hari.Keperluan memasak dan minum masyarakat terpenuhi dengan menggunakan air hujan, namun jika kamarau tiba masyarakat sangat sulit mendapatkan air bersih layak konsumsi.

Desa Kundur berinisiatif melakukan perubahan agar masalah yang setiap tahunnya terus dihadapi bisa teratasi dan memberikan kemudahan bagi masyarakat desa. Melalui Dinas Pemberdayaan Masyarakat dan Desa Kabupaten Kepulauan Meranti, Desa Kundur 
mengajukan proposal permohonan Direktorat Pendayaagunaan Sumber Daya Alam dan Teknologi Tepat Guna (SDA-TTG), Ditjen Pembangunan dan Pemberdayaan Masyarakat Desa (PPMD) Kementerian Desa, Pembangunan Daerah Tertinggal dan Transmigrasi (Kementerian Desa, PDTT). Proposal yang diajukan berbuah manis, Kementrian Desa PDTT menyetujui usulan Desa Kundur untuk melakukan pengelolaan air gambut menjadi air bersih dengan menggunakan teknologi tepat guna dan memberikan bantuan berupa fasilitas pengelolaan air gambut menjadi air bersih serta memberikan pembinaan terhadap pengurus BUMDes yang menjadi pengelola unit air bersih di Desa Kundur.

Potensi gambut yang selama ini dianggap tidak memberikaan pengaruh apapun, ternyata dengan sentuhan teknologi dan kreatifitas memberikan keberkahan bagi masyarakat dan desa.Penerapan teknologi tepat guna yang bertujuan memanfaatkan sumber daya alam desa sebagai pemenuhan kebutuhan warga, memajukan ekonomi desa, penguatan kapabilitas masyarakat, dan peningkatan partisipasi masyarakat dengan mendorong pembentukan, pengembangan dan penguatan serta mendorong tumbuhnya teknologi dibidang tersebut.Dari tujuan yang dikehendaki, teknologi tepat guna haruslah menerapkan metode yang hemat sumber daya, mudah dirawat, dan berdampak polutif seminimal mungkin dibandingkan dengan teknologi arus utama, yang pada umumnya beremisi banyak limbah dan mencemari lingkungan (Rahmiyati et al., 2015).

Komitmen pemerintah untuk menerapkan pemberdayaan masyarakat melalui teknologi tepat guna telah tertuang dalam Permendes PDTT No 23 tahun 2017 Tentang Pengembangan dan Penerapan Teknologi Tepat Guna dalam Pengelolaan Sumber Daya Alam. Teknologi tepat Guna akan baik apabila teknologi itu sebanyak mungkin mempergunakan sumber-sumber yang tersedia banyak di suatu tempat, apabila teknologi itu sebanyak mungkin mempergunakan sumber-sumber yang terdapat sedikit di suatu tempat, apabila teknologi itu dapat sesuai dengan keadaan ekonomi dan sosial masyarakat setempat, dan teknologi itu membantu memecahkan persoalan atau masalah masyarakat (Nugraha \& Mahida, 2013).

Sebagai bentuk praktik terbaik dari Permendes PDTT No 23 tahun 2017 Tentang Pengembangan dan Penerapan Teknologi Tepat Guna dalam Pengelolaan Sumber Daya Alam pasalnya pengelolaan air minum tersebut mendapatkan penghargaan dari Kementrian Desa Pembagunan Daerah Tertinggal dan Trasmigrasi yakni peringkat 1 Desa Terbaik Nasional Kategori Prakarsa dan Inovasi Desa tahun 2018 serta penghargaan tingkat Provinsi dan Kabupaten yang didapat oleh Desa Kundur penghargaan ini diperoleh dari inovasi Desa Kundur dalam memberikan ide pengembangan air minum dari air gambut.Praktik terbaik atau yang disebut best practice adalah suatu inovasi yang diterapkan ditengah-tengah masyarakat dengan harapan dapat memberikan pengaruh dan perubahan yang baik terhadap wilayah tersebut. Best practice dilakukan karena adanya permasalahan yang tidak kunjung selesai disuatu wilayah. Pengertian best practice sendiri masih sangat minim ditemukan, karena menurut (Eldo \& Mutiarin, 2019) best practice sendiri hanyalah predikat yang diberikan terhadap indikator-indikator penting yang tidak dapat digeneralisasikan kesetiap aspek yang telah ada. Secara sederhana dapat disimpulkan bahwa best practice adalah hal khusus yang dianggap penting dalam suatu aspek.

Menurut Kementrian Pendayagunaan Aparatur Negara dan Reformasi Birokrasi Republik Indonesia dalam (Parasuraman, 2011) best practice didefenisikan terkait dengan 
Berbagai inovasi kalangan birokrasi menghasilkan apa yang disebut sebagai praktek terbaik. Penghargaan tersebut menunjukkan bahwa best practice dari Permendes PDTT No 23 tahun 2017 Tentang Pengembangan dan Penerapan Teknologi Tepat Guna dalam Pengelolaan Sumber Daya Alam berhasil diterapkan di Desa Kundur. Keberhasilan pengelolaan air minum di Desa Kundur tersebut yang memanfatkan teknologi tepat guna dilihat sebagai best practice dalam penyelenggaraan Peraturan Kementrian Desa Pembangunan Daerah Tertinggal dan Transmigrasi Nomor 23 tahun 2017 Tentang Pengembangan dan Penerapan Teknologi Tepat Guna dalam Pengelolaan Sumber Daya Alam ditengah-tengah masyarakat pasalnya ada beberapa wilayah tidak mampu dan berhasil dalam mengembangkan dan menerapkan teknologi tepat guna dalam membantu masyarakat. Atas permasalah yang diuraikan diatas, peneliti tertarik untuk melakukan penelitian terlebih lanjut yang dibuat dalam karya ilmiah yang membahas Best Practice Pengembangan dan Penerapan Teknologi Tepat Guna pengelolaan air bersih di Desa Kundur Kecamatan Tebing Tinggi Barat Kabupaten Kepulauan Meranti serta faktor-faktor yang mempengaruhinya.

\section{METODE PENELITIAN}

Jenis penelitian yang digunakan dalam penelitian ini adalah metode penelitian kualitatif dengan pendekatan studi kasus yang bersifat deskriptif.Penelitian kualitatif yang dilakukan dalam penelitian kali ini adalah berawal dengan memahami fenomena secara menyeluruh yang terjadi di Desa Kundur terkait dengan penerapan pengelolaan air bersih. Selanjutnya menyusun rencana-rencana yang akan dilakukan saat penelitian berlangsung seperti menentukan masalah yang ingin dibahas dan tujuan dari penelitian, menentukan draft wawancara sesuai dengan teori yang digunakan dalam penelitian, melakukan observasi secara langsung dilingkungan Desa Kundur dan dokumentasi. Tidak hanya itu upaya-upaya penting lainnya yang melibatkan prosedur penelitian seperti mengumpulkan data, memilah dan menganalisis data, dan menulis data dalam bentuk tulisan-tulisan secara alamiah secara nyata.Penyajian data diperoleh dari hasil penelitian melalui wawancara dan observasi langsung terhadap lokasi penelitian yakni Unit Air Bersih Desa Kundur dan kepada Masyarakat yang menjadi pengguna air bersih tersebut.

\section{HASIL DAN PEMBAHASAN}

Penelitian ini akan berfokus kepada Penerapan Teknologi Tepat Guna (TTG) yang dilakukan oleh Desa Kundur sebagai bentuk best practice pengembangan dan penerapan teknologi tepat guna dalam pengelolaan sumber daya alam yang sesuai dengan Peraturan kementrian Desa, Pembangunan Daerah Tertinggal, dan Transmigrasi Republik Indonesia Nomor 23 Tahun 2017 melalui BUMDes dengan program pengelolaan air gambut menjadi air minum serta apa saja yang menjadi faktor penghambat dalam penerapan teknologi tepat guna pengelolaan air minum di Desa Kundur Kecamatan Tebing Tinggi Barat Kabupaten Kepulauan Meranti.

Penyajian data yang dilakukan oleh peneliti di dalam bab ini diperoleh dari hasil penelitian melalui wawancara dan observasi langsung terhadap lokasi penelitian yakni Unit Air Bersih Desa Kundur dan kepada Masyarakat yang menjadi pengguna air bersih tersebut. Data mentah yang telah diperoleh dianalisis dengan menggunakan teknik analisis data Miles dan 
Huberman. Penelitian ini menggunakan kriteria best practice yang meliputi dampak, kemitraan dan patnerrship hal tersebut dilakukan agar hasil penelitian sesuai dengan tujuan masalah dan ingin dipecahkan. secara ilmiah maka peneliti menggunakan teori beberapa kriteria untuk menilai sebuah best practice menurut (Prasojo, Eko, 2007) berikut ini pembahasannya secara lengkap :

\section{Dampak ( Impact )}

Dampak yang dirasakan dari sisi pemerintah dapat diukur dari tercapainya beberapa tujuan visi dan misi pemerintah desa kundur, Desa Kundur merasakan dampak fositif yang banyak setelah implementasi teknologi tepat guna pengelolaan air gambut menjadi air bersih ini dilakukan, secara langsung pemerintah mengalami penambahan terhadap Pendapatan Asli Desa Kundur. Sebelumnya hanya dari sektor pertanian tapi saat ini ada penambahan dari usaha air bersih. Berikut ini adalah hasil dari keuntungan Unit Pengelolaan Air Minum di Desa Kundur yang merupakan Bentuk Praktik Terbaik dari Peraturan Kementrian Desa Pembangunan Daerah Tertinggal dan Transmigrasi Nomor 23 tahun 2017 Tentang Pengembangan dan Penerapan Teknologi Tepat Guna dalam Pengelolaan Sumber Daya Alam ditengah-tengah masyarakat.

Pendapatan tersebut telah menyumbangkan penghasilan BUMDes Bina Usaha Sejati dalam pendapatan Asli Desa Kundur. Hal tersebut dapat dilihat dalam tabel berikut ini :

Pengelolaan air minum ini baru berjalan aktif pada tahun 2020, setelah aktif beroperasi pengelolaan air minum salwa tersebut menghasilkan pendapatan yang cukup meningkat tiap bulannya, tetapi dikarenakan virus covid-19 yang menyerang Indonesia secara tidak langsung juga melumpuhkan pendapatan dari pengelolaan air minum salwa hal tersebut dikarenakan adanya pengurangan karyawan diperusahaan-perusahaan yang menjadi konsumen air minum tersebut. Selain itu Desa Kundur mendapatkan penghargaan dari Kementrian Desa Pembangunan Daerah Tertinggal dan Transmigrasi yakni peringkat 1 Terbaik Nasional Kategori Prakarsa dan Inovasi Desa. yang membawa nama Desa Kundur ke kancah nasional sehingga Desa Kundur mendapatkan perhatian dan respon positif dari pemerintah daerah serta menjadi contoh bagi pemerintah daerah dan desa lainya untuk mengembangkan desa mereka. Akibat dari itu Desa Kundur menjadi wisata pendidikan, maksudnya banyak para peneliti datang untuk belajar dan penasaran terhadap teknologi tepat guna air gambut yang diolah menjadi air bersih ini baik itu untuk mengadopsi inovasi ataupun sekedar mencari tahu kebenaran yaitu melakukan penelitian.

Hal tersebut ditemukan dari wawancara peneliti dengan informan penelitian berikut ini hasil wawancaranya :

"Paling pertama itu PADes bertambah, bukan secara langsung nambah banyak tetapi adalah pemasukan dari usaha desa. Kedua itu dapat penghargaan kemarin termasuk dampakjuga kan. Terus banyak yang datang untuk penelitian, kemarin yang dari papua sempat mau datang tapi terhalang corona.Setidaknya bisalah sebaga bentuk kami berusaha mengembangkan 


\section{ekonomi desa ini'.'(wawancara dengan Bapak Saringat S.Pd.I selaku}

Sekertaris Desa Kundur Kecamatan Tebing Tinggi Barat Kabupaten

Kepulauan Meranti,28 Desember 2020).

Salah satu usaha yang BUMDes Kelola, Pendapatan BUMDes bertambah otomatis PADes juga ya. Desa Kundur bisa menjadi contoh yang baiklah atau memotivasi Pemerintah dan desa lain untuk seperti kami maksudnya mengembangkan usaha gitu. Kemarin juga dapat penghargaan dari nasional mengenai inovasi ini.Sudah itu karna karyawan dari masyarakat setidaknya adalah pekerjaan dan penghasilan tambahan.Mungkin kalau secara pribadi ya mudah dapat air bersih sekarang lebih terjamin juga'.(wawancara dengan Bapak Misgiani selaku Kepala Unit Air Bersih Desa Kundur Kecamatan Tebing Tinggi Barat Kabupaten Kepulauan Meranti, 21 Desember 2020).

Secara tidak langsung akibat dari usaha air bersih ini banyak masyarakat yang menjadi tenaga kerja sehingga mengurangi pengangguran, menambah pendapatan, dan membantu ekonomi masyarakat. Sedangkan dari sisi masyarakat, kemudahan yang didapat masyarakat dalam mendapatkan air bersih dengan harga yang terjangkau dan kualitas terjamin.Selama ini masyarakat menggunakan air hujan untuk dikonsumsi dan keperluan memasak atau membeli galon dari luar desa.Karena Desa Kundur lumayan jauh dari perkotaan mengakibatkan harga jual air galon cukup mahal apalagi dimusim kemarau.Tetapi masih ada masyarakat yang lebih memilih mengkonsumsi air hujan ataupun air gambut hal tersebut karena kebiasaan meminum air hujan dari dahulu sehingga air hasil produksi ini tidak sesuai dengan yang diinginkan, kebanyakan yang tidak meminum adalah masyarakat yang tergolong tua.

\section{Dampak Negatif}

Menurut hasil wawancara tidak ada informan yang menyatakan hal negatif mengenai penerapan teknologi tepat guna pengelolaan air gambut menjad air bersih ini. Tetapi menurut peneliti sesudah dianalisis dengan seksama muncul pemikiran bahwa jika setiap masalah ditangani oleh pemerintah maka akan muncul sifat ingin difasilitasi dalam setiap kegiatan baik itu pemerintah desa ataupun masyarakat. Takutnya dengan terbukanya Pemerintah Desa kedepan masyarakat akan menganggap mudah segala masalah yang dialami dan melempar kepada pemerintah desa sehingga tidak mampu lagi mencari jalan keluar sendiri. Selain itu susahnya pemeriah desa dan BUMDes membagikan dana penyertaan modal untuk setiap usaha karena kebutuhan usaha yang semakin besar.

\section{Kemitraan (Patnership)}

Komitmen Kementrian Desa PDDT juga tidak main-main dalam menyukseskan program ini. Tidak hanya sekedar merencanakan saja Kementrian Desa PDDT melalui tim pelaksana Program bekerjasama dengan perusaahaan ahli dibidangnya untuk menciptakan mesin dengan teknologi tepat guna sesuai dengan fungsi dan kebutuhan yang akan membantu masyarakat Desa Kundur. Mesin teknologi tepat guna pengelolaan air gambut dibuat oleh PT Osmo pacific abadi yang bergerak dibidang pengadaan alat- alat industri dan pengolahan air. Kementrian Desa Pembangunan Daaerah Tertinggal dan Transmigrasi melakukan kerjasama dengan PT Osmo Pacific abadi dalam menciptakan teknologi yang sesuai. Hal tersebut dilakukan tentu saja karena pengadaan teknologi harus sesuai ahli dan bidangnya agar tidak terjadi kesalahan 
dan kegagalan yang tidak diinginkan. PT Osmo Pacific Abadi sebagai penggarap teknologi tepat guna mesin pengolahan air gambut menjadi air bersih tentunya memiliki kepentingan untuk perusahaan mereka yakni mengenai keuntungan dan benefit yang didapat, dalam sektor privat benefit adalah tujuan sehingga PT Osmo mampu menghasilkan teknologi yang memberikan keuntungan bagi perusahaan mereka.

\section{Keberlanjutan (Sustainbility)}

Dalam aspek keberlanjutan dilihat manfaat apa yang dirasakan masyarakat. Setelah dilakukan penerapan teknologi tepat guna pengeloaan air gambut menjadi air bersih di Desa Kundur, masyarakat sangat menerima dan terbuka atas program yang dibuat oleh pemerintah Desa Kundur dibuktikan dengan perubahan yang dilihat secara langsung. Bahkan masyarakat menginginkan air bersih tersebut dialiri kerumah masing- masing.Dari 100\% hasil air, 40\% air bersih yang bisa langsung dikonsumsi, sedangkan $60 \%$ hasil air harus di masak dahulu untuk dikonsumsi. Rencananya air yang akan dialiri kerumah-rumah masyarakat adalah air hasil $60 \%$ yaitu air yang harus dimasak dahulu sebelum dikonsumsi. Berbeda dengan air yang dijual dalam bentuk galon dan kedepannya akan diproduksi Air Minum Dalam Kemasaan.

Berikut ini hasil wawancara peneliti dengan informan penelitian yang menegaskan bahwa unit air bersih ini sudah memiliki program kerja yang akan direncanakan, hal tersebut dilakukan karena banyak masyarakat memberikan masukan-masukan untuk penyaluran air ini. Hal tersebut menunjukkan bahwa manfaat yang dirasakan masyarakat sangat fositif. Berikut ini hasil wawancaranya: "Semakin bertambah ilmu, sekarang banyak pelatihan-pelatihan yang dilakukan jadi menambah relasi juga, banyak juga kemudahan-kemudahan karena sudah memiliki pengalaman ini.Kalau dari segi penerimaan masyarakat sangat mendukung sekali bahkan mereka minta airnya itu dialirkan kerumah-rumah, tapi air yang di tower itu tetapi masih kami pikirkan'. (Wawancara dengan Bapak Misgiani selaku Kepala Unit Air Bersih Desa Kundur Kecamatan Tebing Tinggi Barat Kabupaten Kepulauan Meranti, 21 Desember 2020).

Perubahan bisa terjadi secara langsung setelah dilakukannya implementasi kebijakan atau memerlukan waktu sekian lama agar bisa melihat perubahan yang terjadi didalam masyarakat hal tersebut dipengaruhi oleh terbuka atau tidaknya masyarakat terhadap hal yang baru. Setiap perubahan memiliki proses yang memakan waktu, karena membiasakan diri dengan sesuatu yang baru adalah hal yang sulit. Maksudnya perubahan yang dapat dilihat secara langsung adalah efek yang sangat terasa setelah adanya penerapan tersebut, tidak secara total berubah langsung tatanah kehidupan masyarakat tetapi perubahan yang besar sesuai tujuan kebijakan tersebut diimplementasikan.

Seperti halnya Desa Kundur sangat mengalami perubahan setelah adanya penerapan teknologi tepat guna pengelolaan air gambut menjadi air bersih. salah satunya adalah masyarakat yang terbiasa mengkonsumsi air hujan sekarang tidak lagi karena adanya air bersih, masyarakat merasa aman dan terjamin terhadap air minum yang dikonsumsinya. Selain itu jika dahulu musim kemarau adalah musim yang menjadi beban bagi masyarakat atas kekurangan air tapi saat ini tidak lagi. Masyarakat yang dahulunya harus mengeluarkan uang lebih untung air galon yang datang dari luar desa karena musim kemarau harga menjadi naik, saat ini tidak lagi cemas akan hal tersebut. 
Kemampuan beradaptasi masyarakat berbeda-beda, ada yang mudah melakukannya dan ada juga yang sulit untuk membuka dirinya terhadap hal yang baru dilingkungan tempat tinggalnya.Sama halnya dengan beberapa masyarakat yang belum menerima untuk mengkonsumsi air bersih hasil produksi BUMDes tersebut, dikarenakan sudah terbiasa menggunakan air hujan atau air gambut untuk dikonsumsi. Tetapi menurut informan hanya masyarakat dengan umur yang sudah tua saja maksudnya adalah lansia yang sudah terbiasa secara temurun-temurun mengkonsumsi air hujan dan air gambut belum bisa beradaptasi dengan hal yang baru karena kebiasaan yang sudah lama dilakukan.

Dari sisi pemerintahan Desa Kundur perubahan yang dirasakan belum terlalu besar tetapi sesuai harapan. Pendapatan Desa yang bertambah adalah salah satu tujuan yang diharapkan, walaupun penambahan belum terlalu signifikan tetapi sudah memberikan pengaruh tehadap penambahan pendapatan Desa Kundur. Selain itu dapat dilihat bahwa adanya motivasi dan kemauan belajar dari lembaga-lembaga yang ada di Desa Kundur untuk mengembangkan teknologi tepat guna lainya agar bisa memudahkan pekerjaan masyarakat sehari-hari.Tidak hanya itu penerapan teknologi tepat guna pengelolaan air gambut menjadi air bersih di Desa Kundur membawa perubahan yakni dahulunya Desa Kundur seperti desa pada umumnya tetapi semenjak adanya penerapan program tersebut banyak yang datang ke Desa Kundur untuk belajar dan melakukan penelitian terhadap air bersih baik dari dalam daerah maupun luar daerah. Sisi positif lainnya adalah banyak ilmu baru yang didapat para pengelola air bersih terkait dengan teknologi dan pengembangan terhadap usaha.

Saat ini perubahan secara besar belum terlihat tetapi dikarenakan setiap perubahan tidak bisa secara instan, diharapkan perubahan besar lainnya bisa dirasakan seiring perkembangan zaman agar berdampak bagi kehidupan masyarakat dan Desa Kundur jangka panjang. Jika dilihat dari perubahan-perubahan kecil yang dirasakan masyarakat, tentunya akan memberikan perubahan besar jika pengembangan terhadap pengelolaan air minum ini terus dilanjutkan. Mengapa demikian karena pengembangan ini tepat sasaran yaitu masyarakat yang memang membutuhkan air minum yang layak. Jika masyarakat membutuhkannya masyarakat akan bergantung secara terus menerus, hal tersebut diharapkan membawa pengaruh positif terhadap keberlanjutan pengembangan teknologi tepat guna air minum ini. Selain itu kondisi wilayah yang berpulau secara otomatis air yang dihasilkan payau tentunnya teknologi ini sangat dibutuhkan. Kemudian teknologi tepat guna pengelolaan air minum ini satu-satunya yang ada di Kabupaten Kepulauan Meranti secara otomatis jika dikembangkan dan dikelola dengan baik maka pengelolaan air minum ini akan berpengaruh besar terhadap pemenuhan pasokan air minum yang layak di Kabupaten Kepulauan Meranti. Untuk memperkuat analisis diatas peneliti melakukan beberapa perbandingan dengan penelitian lainnya yang membahas mengenai teknologi tepat guna untuk mendukung hasil penelitian ini lebih kuat, berikut ini hasilya:

Dalam penelitian yang berjudul penerapan tenologi tepat guna pengelolaan air payau menjadi air bersih dikelurahan dalam Kabupaten Sampang yang ditulis oleh Sumargono, Laksmono, dan Lilik Supriyanti menjelaskan bahwa penerapan teknologi tepat guna dalam memecahkan masalah air lebih cepat dan efisien karena alat tersebut memang di design untuk masalah yang sudah dipelajari secara matang. Teknologi tepat guna muncul akibat seiring permasalahan yang penyelesaian masalahnya tidak sesuai dan tidak efisien, dikarenakan tidak 
ada kajian khusus mengenai masalah tersebut, berbeda dengan teknologi tepat guna setiap permasalahan yang dialami masyarakat harus melewati beberapa proses seperti yang telah tertuang dalam Permendes PDDT No 23 Tahun 2017 Tentang Pengembangan dan Penerapan Teknologi Tepat Guna Pengelolaan Sumber Daya Alam. Selain itu untuk menunjukkan bahwa pengelolaan air minum di Desa Kundur ini merupakan praktik terbaik dari inovasi tersebut ialah berhasil mendapatkan penghargaan peringkat 1 kategori prakarsa dan inovasi desa tingkat nasional. Dalam penelitian yang berjudul pengembangan produksi dodol mangrove melalui penerapan teknologi tepat guna yang ditulis oleh M. Fitria, Elvy Sahnur Nasution menjelaskan bahwa teknologi tepat guna sebagai jalan keluar bagi masalah-masalah yang dihadapi oleh masyaraakat, memberikan kemudahan, dan berdampak terhadap ekonomi masyarakat dan kesejatraan masyarakat.

\section{KESIMPULAN}

Hasil penelitian menunjukkan bahwa pengembangan dan penerapan teknologi tepat guna pengelolaan air minum di Desa Kundur berhasil diterapkan dan berjalan dengan baik sesuai dengan proses yang termaktub dalam Permendes PDDT nomer 23 tahun 2017 tentang pengembangan dan penerapan teknologi tepat guna pengelolaan sumber daya alam. Pengembangan dan penerapan teknologi tepat guna pengelolaan air minum tersebut memberikan dampak yang baik bagi masyarakat dan pemerintah Desa Kundur. Seperti memudahkan masyarakat mendapatkan air bersih, menambah pendapatan Asli Desa walaupun belum maksimal, memotivasi masyarakat desa untuk giat berusaha mengembangkan teknologi tepat guna lainnya untuk memudahkan pekerjaan masyarakat Desa Kundur, mengurangi pengangguran dan menambah pendapatan masyarakat bagi yang menjadi karyawan, dan adanya penambahan ilmu terhadap bagaimana mengelola usaha dibidang bisnis dengan baik bagi pengelola. Hasil penelitan menemukan bahwa faktor-faktor yang menjadi penghambat dalam penerapan teknologi tepat guna pengelolaan air gambut menjadi air bersih dalam upaya mengembangkan ekonomi desa di Desa Kundur adalah Strategi pemasaran, Legalitas hukum yang belum lengkap dan anggaran atau dana yang masih minim.

Hal-hal yang dapat peneliti sarankan dalam menimimalisir faktor penghambat jalannya pengelolaan air gambut menjadi air bersih adalah sebagai berikut; Pemerintah Desa Kundur hendaknya melakukan evaluasi terhadap kinerja pengelola unit air bersih dan Badan Usaha Milik Desa Bina Usaha Sejati Desa Kundur. Evaluasi diperlukan dalam setiap organisasi, hal tersebut dilakukan agar tidak terjadi kelalaian dan kesalahan yang berulang dalam kinerja serta meningkatkan motivasi karyawan dan kualitas produk yang dihasilkan. Saran yang dapat penulis berikan terkait poin kedua yaitu a. menetukan strategi pemasaran dengan baik, seperti iklan menggunakan reklame dijalan, brosur, dan poster dan melakukan perbaikan terhadap packaging kemasan galon agar terlihat lebih rapi dan bersih. c. Mempersiapkan izin secepat mungkin agar legalitas hukum yang dimiliki jelas. d. Menjalin hubungan dengan perusahaan secara timbal balik untuk mensponsori penambahan modal unit usaha pengelolaan air bersih tersebut. 


\section{DAFTAR PUSTAKA}

Bungin, B. (2007). Analisis Data Penelitian Kualitatif. Jawa Barat: Pt Raja Grafindo Persada. Eko, S. (2014). Desa Membangun Indonesia. In Academia.Edu. https://doi.org/10.1038/ncomms12854

Eldo, D. H. A. P., \& Mutiarin, D. (2019). Analisis Best Practice Inovasi Pelayanan Publik (Studi pada Inovasi Pelayanan "Kumis MbahTejo" di Kecamatan Tegalrejo Kota

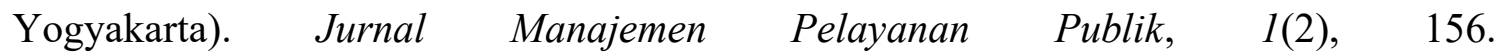
https://doi.org/10.24198/jmpp.v1i2.16753

Febriani, Y. (2019). Pembuatan Sistem Pengolahan Air Gambut Menjadi Air Bersih. (March). Fitra, M., \& Nasution, E. S. (2019). Pengembangan Produksi Dodol Mangrove Melalui Penerapan Teknologi Tepat Guna. 1(1), 350-354.

Heriyanto, M., Adianto, \& As'ari, H. (2019). Model Implementasi Program Csr Di Indonesia Praktek Di Pt Pertamina Ru Ii Dumai Dan Pt Cevron Pacifik Indonesia (Cpi) Riau. Pekanbaru: Taman Karya Pekanbaru.

Kurniawan, B. (2016). Desa Mandiri, Desa Membangun. Jakarta: Kementerian Desa, Pembangunan Daerah Tertinggal, Dan Transmigrasi Republik Indonesia.

Moko, E. M., Rahardiyan, D., \& Wantouw, F. (2020). Penerapan Teknologi Filtrasi Dan Tower Penampungan Low Cost- Low Maintenance Dalam Penyediaan Air Bersih Bagi Masyarakat Desa Bango Kepulauan Mantehage. 2, 20-25.

Nugraha, D. H., \& Mahida, M. (2013). Pengolahan Air Minum ( Studi Kasus : Pulau Palu 'E , Nusa Tenggara Timur) Community Readiness In The Application Of Technology Of Drinking. 119-129.

Rahmiyati, N., Andayani, S., \& Panjaitan, H. (2015). Model Pemberdayaan Masyarakat Melalui Penerapan Teknologi Tepat Guna Di Kota Mojokerto. Jurnal Ilmu Ekonomi \& Manajemen, 2(2), 48-62. Retrieved From Http://Jurnal.UntagSby.Ac.Id/Index.Php/Jmm17/Article/View/506/463

Silalahi, U. (2017). Metode Penelitian Sosial (Cetakan Pe; A. Gunarsa, Ed.). Bandung: Pt Radika Aditama.

\section{Peraturan}

Undang- Undang No 6 Tahun Tentang Desa

Permendes Pdtt No 23 Tahun 2017 Tentang Pengembangan Dan Penerapan Teknologi Tepat Guna Dalam Pengelolaan Sumber Daya Alam

Peraturan Desa Kundur No 4 Tahun 2017 Tentang Badan Usaha Milik Desa Kundur 